\title{
Screening of microfungi for lipolytic activity and optimization of process parameters in lipase production by solid substrate fermentation using selected microfungi (Penicillium aurantiogriseum)
}

\author{
Meltem Çakmak ${ }^{1}$, Halide Aydoğdu,** \\ ${ }^{\prime}$ Dept. of Biotechnology and Genetics, Institute of Science, Trakya University, Edirne, Turkey \\ ${ }^{2}$ Arda Vocational College, Trakya University, Edirne, Turkey \\ *Corresponding author: halideaydogdu@trakya.edu.tr
}

\begin{abstract}
In the present study, eighty-four strains of microfungi were screened for lipolytic activity, and Penicillium aurantiogriseum showing the highest enzyme activity was selected. Then extracellular lipase production from this species was carried out using the solid state fermentation (SSF) method, in which various agricultural wastes were used as substrates. Among the various agricultural wastes used in SSF, sunflower pulp was determined as the best solid substrate. Optimum fermentation conditions were found as follows: 6-day incubation time at $25^{\circ} \mathrm{C}$ and moisturizing liquid pH: 5.5 (distilled water), initial moisture level $75 \%(\mathrm{w} / \mathrm{v})$, initial inoculum concentration $1 \mathrm{ml}\left(1 \times 10^{6}\right.$ spores $\left./ \mathrm{ml}\right)$, and 1\% sesame oil as a carbon source. As a result of the optimum conditions, the volume activity was recorded as $0.4 \mathrm{U} / \mathrm{ml}$, and the specific enzyme activity was obtained as $1.13 \mathrm{U} / \mathrm{mg}$.
\end{abstract}

Keywords: lipase; microfungi; optimization; Penicillium aurantiogriseum; SSF.

\section{Introduction}

Lipases (triacylglycerol hydrolase E.C. 3.1.1.3) that hydrolyze fatty acid ester bonds in aqueous environments are one of the most important groups of industrial enzymes (Jain ve Naik, 2018). As the use of biocatalysts in industrial processes has been continuously expanding, the demand for lipase production is increasing (Sarmah et al., 2018). The fact that lipases can catalyze very specific chemical transformation reactions is an important factor in the widespread use in food, chemical, pharmaceutical, and detergent industries (Singh \& Mukhopadhyay, 2012). Although they can be obtained from many plant and animal sources, microorganisms, especially fungi, are preferred more in lipase production (Sarmah et al., 2018). Lipase enzymes can be obtained from many different fungal species; however, enzyme production requires the provision of suitable environmental conditions such as substrates, $\mathrm{pH}$, and temperature to the microorganisms. In addition, the produced lipases can have different properties. Thus, screening for extracellular enzyme activities and searching for suitable environmental conditions are of great importance for commercially large-scale lipase production (Shabbir \& Mukhtar, 2018). Many biocatalysts, such as lipases, can be produced by submerged fermentation (SmF) or solid-state fermentation (SSF) (Martínez-Ruiz et al., 2018). However, SSF is reported to be the best direct method for the production of fungal extracellular enzymes (Geoffry \& Achur, 2018). Optimization of fermentation conditions (incubation temperature, $\mathrm{pH}$, moisture, amount of inoculum, carbon source, incubation time, etc.) is very important in using this method (Rodrigues et al., 2016; Manoorkar ve Gachande, 2015; de-Almeida et al., 2013; Malilas et al., 2013; Iftikhar et al., 2011). Also, screening of new microorganisms and using cheap culture media are among the important issues in enzyme production (Martínez-Ruiz et al., 2018). Thus, alternative substrates are proposed for the production of enzymes. Agricultural and industrial wastes are preferred as an alternative substrate, because of their economic and ecological characteristics (Ferreira et al., 2017). Industrial lipases are produced mainly by filamentous fungi, particularly Aspergillus, Rhizopus, Penicillium, Mucor, Geotrichum, and Fusarium (Manoorkar \& Gachande, 2015; Iftikhar et al., 2011; Lima et al., 2004; Cardenas et al., 2001; Pandey et al., 1999).

P. aurantiogriseum is a commonly found species in nature growing in the presence of grain-derived products. In this study, screening for fungal lipases was performed, and optimization studies were carried out using $P$. aurantiogriseum, which is determined to be the 
best enzyme producer, and using agricultural wastes as substrates in SSF culture medium. The effects of various fermentation conditions on lipase enzyme activity of $P$. aurantiogriseum were investigated, and optimum conditions were determined.

\section{Materials and methods}

\subsection{Supply of microfungi}

In this study, 84 microfungi strains (62 species belonging to 21 genera: Alternaria, Aspergillus, Arthrinium, Acremonium, Beauveria, Cladosporium, Cochliobolus, Dendryphion, Didymella, Fusarium, Geotrichum, Gibberella, Graphiopsis, Penicillium, Pochonia, Ramichloridium, Rhizopus, Scopulariopsis, Talaromyces, Trichothecium, Trichoderma), obtained from Trakya University Arda Vocational School, were screened for extracellular lipase production potentials.

\subsection{Screening lipase production}

The lipolytic activities of microfungi strains were tested in lipase media containing $1 \%$ tributyrin in test tubes. Test microfungi were incubated in Petri plate with Potato Dextrose Agar (PDA) medium for 7 days at $25^{\circ} \mathrm{C}$. The mycelial discs $(5 \mathrm{~mm})$, obtained with sterile cork borer from 7-day colonies of test isolates, were placed on top of lipase media. The media were then incubated at $25^{\circ} \mathrm{C}$ for up to 7 days (Topal et al., 2000). The microfungi species, which showed the best activity, were transferred on slant PDA media, and these cultures were kept in the refrigerator at $+4^{\circ} \mathrm{C}$ to be used as stock culture. Fresh fungal cultures have been always used in studies.

\subsection{SSF culture medium and enzyme extraction}

Wheat bran (WB), corn pulp (CP), sunflower pulp (SP), and their mixture (equal amounts $\mathrm{WB}, \mathrm{CP}$, and $\mathrm{SP}$ ) were used as substrate for preparing SSF culture medium. These substrates were dried in a sterilizer at $80^{\circ} \mathrm{C}$ for 24 hours, and then $5 \mathrm{~g}$ of substrates was placed in $250 \mathrm{ml}$ Erlenmeyer flasks. After scaling the moisture content of the medium with distilled water, sterilization was achieved in the autoclave at $121^{\circ} \mathrm{C}$ for $15 \mathrm{~min}$.

The 7-day-old cultures grown in PDA of the strain, which had the highest activity on lipase medium with tributyrin, were washed with sterile distilled water and passed through 4-fold sterile gauze. These spore suspensions were then scaled to $10^{6} \mathrm{spores} / \mathrm{ml}$ and transferred to the SSF medium as $1 \mathrm{ml}$ (Sadh et al., 2018). SSF media, which were not transferred microfungi, were used as control. At the end of the incubation period at $25^{\circ} \mathrm{C}$ for 7 days, $50 \mathrm{ml}$ of distilled water was added to the all SSF media including control and shaken in a 200 rpm for $60 \mathrm{~min}$. The content was firstly filtered through sterile gauze and then through Whatman No. 1 filter paper. The obtained filtrates were used as enzyme source for determination of enzyme activities (Iftikhar et al., 2010).

\subsection{Lipase activity assay}

Extracellular lipase enzyme activities were measured spectrophotometrically. In the measurement of lipase activity, the method proposed by Hung et al. (2003) was modified (p-nitrophenyl palmitate hydrolysis method and examined by a spectrophotometer). For the assay, the reaction mixture consisting of $1 \mathrm{ml}$ solution of p-nitrophenyl palmitate (PNPP) (prepared with ethanol) and $1 \mathrm{ml}$ of enzyme extract was stirred at $40^{\circ} \mathrm{C}$ for $5 \mathrm{~min}$ to perform a hydrolysis reaction. The hydrolytic reaction was stopped by adding $2 \mathrm{ml}$ of $0.5 \mathrm{~N}$ sodium carbonate, and enzyme solution was centrifuged at $10000 \mathrm{x}$ g for 10 $\min$. The absorbance was measured at $404 \mathrm{~nm}$ from the supernatant (diluted 1/25) against a blank. One unit of enzyme (U) was defined as the amount of enzyme required to release $1 \mu \mathrm{mol}$ of PNP per minute. A specific activity was calculated using the following equation (Takaç \& Şengel, 2009):

Specific Activity $=(\mathrm{U} / \mathrm{ml}) /(\mathrm{mg} / \mathrm{ml}$ protein $)(1)$

\subsection{Protein determination}

Lowry method was used to determine the amount of protein in the determination of a specific activity (Lowry et al., 1951).

2.6 Determination of optimum SSF culture media conditions

To improve the fermentation process, variations of parameters included SSF media components and external factors. Enzyme activity measurements were carried out to determine parameters such as the optimum incubation time (1-10 days), optimum incubation temperature (20, 25,30 , and $\left.35^{\circ} \mathrm{C}\right)$, optimum initial moisture level ( $\% 35$, $\% 55, \% 75$, and $\% 95(\mathrm{w} / \mathrm{v})$, with distilled water), optimum initial inoculum concentration $(0.5,1.0,1.5,2.0,2.5$, and $3.0 \mathrm{ml}$ spore suspensions $\left.\left(1 \times 10^{6} \mathrm{spores} / \mathrm{ml}\right)\right)$, and optimum moisturizing agent $\mathrm{pH}(\mathrm{pH}: 5.0,5.5,6.0,7.0$, and 8.0). Distilled water whose $\mathrm{pH}$ was measured was used as a moisturizing agent. In order to determine the effect of vegetable oils, $1 \%$ olive, sunflower, and sesame oil were added to SSF culture medium as a carbon source. The 
SSF technique was harnessed for the one factor-at-a-time (OFAT) approach to examine various parameters in crude lipase production. In subsequent experiments, parameters that were previously optimized were incorporated (Alhelli et al., 2018).

\subsection{Statistical analysis}

All SSF experiments were performed in 3 replicates. "One-Way Anova" test was used for statistical analysis using Minitab 18 Packaged Program.

\section{Results}

\subsection{Lipolytic activity screening results}

Microfungi species, which makes up the clarity zone in lipase medium, was considered as lipase positive. At the end of the incubation time, transparent zone measurements were made by using digital compass. Penicillium aurantiogriseum was determined to be the best enzyme producer with $19 \mathrm{~mm}$ (Table 1). For this reason, SSF studies were continued with this species.

3.2 The effects and optimization of environmental conditions in SSF culture media on P. aurantiogriseum extracellular lipase synthesis: effect of substrate on SSF culture media

Enzyme activity values of all optimization parameters were calculated by subtracting the control values from P. aurantiogriseum activity values. SSF media prepared with the same conditions and not including microfungi were used as controls (Figure 1).

Table 1. Lipolytic activity values of microfungi strains screened on tributyrin medium on day 7.

\begin{tabular}{|c|c|c|c|}
\hline \multicolumn{4}{|c|}{ LIPOLYTIC ACTIVITY (mm) } \\
\hline $20-15.01 \mathrm{~mm}$ & $15-10.01 \mathrm{~mm}$ & $10-5.01 \mathrm{~mm}$ & $5-0 \mathrm{~mm}$ \\
\hline \multirow{4}{*}{$\begin{array}{l}\text { Penicillium } \\
\text { aurantiogriseum } \\
\text { Aspergillus flavus } \\
\text { (strain1) }\end{array}$} & Penicillium sp.1 & Rhizopus sp.3 & A. alternata (strain2) \\
\hline & Penicillium sp. 2 & Graphiopsis chlorocephala & Beauveria sp. \\
\hline & Rhizopus sp.1 & Penicillium herquei & Fusarium crookwellense \\
\hline & Aspergillus parasiticus & Trichoderma sp.1 & Cladosporium sphaerospermum \\
\hline \multirow{25}{*}{$\begin{array}{l}\text { Penicillium solitum } \\
\text { (strain1) } \\
\text { Rhizopus arrhizus } \\
\text { P. solitum (strain2) } \\
\text { P. solitum (strain3) }\end{array}$} & Aspergillus sp. 1 & Fusarium equiseti & Didymella glomerata \\
\hline & Fusarium poae (strain1) & A. flavus (strain3) & Penicillium sp.5 \\
\hline & Penicillium citrinum & Penicillium sp.4 & A. fumigatus (strain3) \\
\hline & Rhizopus sp.2 & Penicillium oxalicum & F. culmorum (strain3) \\
\hline & Aspergillus sp.2 & Aspergillus versicolor & A. terreus (strain3) \\
\hline & Penicillium bilaiae & Aspergillus terreus (strain1) & Didymella sp. \\
\hline & Cladosporium cladosporioides & Fusarium concolor & A. niger (strain2) \\
\hline & $($ strain1) & Aspergillus fumigatus (strain1) & Geotrichum candidum (strain1) \\
\hline & Penicillium chrysogenum & C. cladosporioides (strain2) & A. niger (strain3) \\
\hline & (strain2) & Penicillium viridicatum & A. niger (strain4) \\
\hline & Rhizopus arrhizus & Aspergillus fumigatus (strain2) & A. niger (strain5) \\
\hline & Penicillium sp.3 & C. cladosporioides (strain3) & Penicillium citrinum \\
\hline & A. flavus (strain2) & Dendryphion comosum & Cochliobolus spicifer \\
\hline & Penicillium chrysogenum & Alternaria citri & F. poae (strain2) \\
\hline & & Fusarium crookwellense & Penicillium digitatum (strain1) \\
\hline & Penicillium brevicompactum & Pochonia chlamydosporium & P. digitatum (strain2) \\
\hline & Aspergillus sp.3 & Gibberella fujikuroi & G. candidum (strain2) \\
\hline & Aspergillus wentii & Trichoderma sp.2 & Talaromyces purpurogenum \\
\hline & Trichothecium roseum & Cladosporium sp.1 & A. niger (strain6) \\
\hline & Scopulariopsis sp. & A. terreus (strain2) & Penicillium sp.6 \\
\hline & Aspergillus flavus var. oryzae & Fusarium culmorum (strain1) & Arthrinium sphaerospermum \\
\hline & Penicillium viridicatum & Ramichloridium subulatum & A. niger $($ strain 7$)$ \\
\hline & & Acremonium sordidulum & \\
\hline & & Alternaria alternata (strain1) & \\
\hline & & Aspergillus niger (strain1) & \\
\hline
\end{tabular}


The enzyme activity value and control value of $P$. aurantiogriseum strain are given separately. Lipase enzyme activity was observed to be $0.05 \mathrm{U} / \mathrm{ml}$ in SSF medium containing mixed substrates and $0.04 \mathrm{U} / \mathrm{ml}$ in SSF medium containing CP (Fig. 1). The study was continued with SSF medium containing SP, which had the highest enzyme activity $0.3 \mathrm{U} / \mathrm{ml}$.

\subsection{Effect of incubation time}

The maximum enzyme activity for $\mathrm{P}$. aurantiogriseum was achieved at day 6. As can be seen in Fig. 1, enzyme production decreased after the 6th day.

\subsection{Effect of incubation temperature}

SSF media containing SP and moistened with distilled water were incubated at different temperatures for 6 days, and the highest enzyme activity was obtained at $25^{\circ} \mathrm{C}$. At $35^{\circ} \mathrm{C}$, enzyme production was not observed (Fig. 1).

\subsection{Effect of initial moisture level}

The best lipase activity was found to be $75 \%(\mathrm{w} / \mathrm{v})$ at the end of 6-day incubation at $25^{\circ} \mathrm{C}$ in $\mathrm{SSF}$ environments with different moisture rations. After $75 \%$, the best activities were determined at 55\% and $35 \%$ moisture levels, respectively. In 95\%, the activity was not observed (Fig. 1).

\subsection{Effect of initial inoculum amounts}

In order to determine the effects of initial inoculum amounts on the production of lipase from $P$. aurantiogriseum in SSF medium, various inoculum levels $(0.5,1,1.5,2,2.5$, and 3 $\mathrm{ml} ; 1 \times 10^{6}$ spores $/ \mathrm{ml}$ ) were transferred to the medium. And the optimum initial inoculum amount was determined as $1.0 \mathrm{ml}$. The volume activities at these inoculum amounts were, respectively, $0.09,0.36,0.05,0.05,0.03$, and 0.01 $\mathrm{U} / \mathrm{ml}$ (Fig. 1).

\subsection{Effect of moistening agents $\mathrm{pH}$}

Moistening agents at different $\mathrm{pHs}$ were added to SSF cultures for $\mathrm{pH}$ evaluation. For these experiments, $\mathrm{pH}$ : 5.0 (potassium phthalate buffer), $\mathrm{pH}: 5.5$ (distilled water), and $\mathrm{pH}$ : 6.0, 7.0, and 8.0 (phosphate buffer) were used. The best lipase activity value was determined in distilled water ( $\mathrm{pH}: 5.5$ ) after 6-day incubation at $25^{\circ} \mathrm{C}$ in SSF medium with $75 \%$ moisture level prepared by adding 1 $\mathrm{ml}$ inoculum amount (Fig. 1).

\subsection{Effect of vegetable oil supplement}

In our study, various vegetable oils were added to the SSF medium as a carbon source by $1 \%$. The highest lipase activity value was determined in SSF medium with sesame oil added after 6 days of incubation at $25^{\circ} \mathrm{C}$ in SSF medium with an initial $\mathrm{pH}$ of 5.5 and $75 \%$ moisture level prepared by adding $1 \mathrm{ml}$ of inoculum amount (Fig. 1).

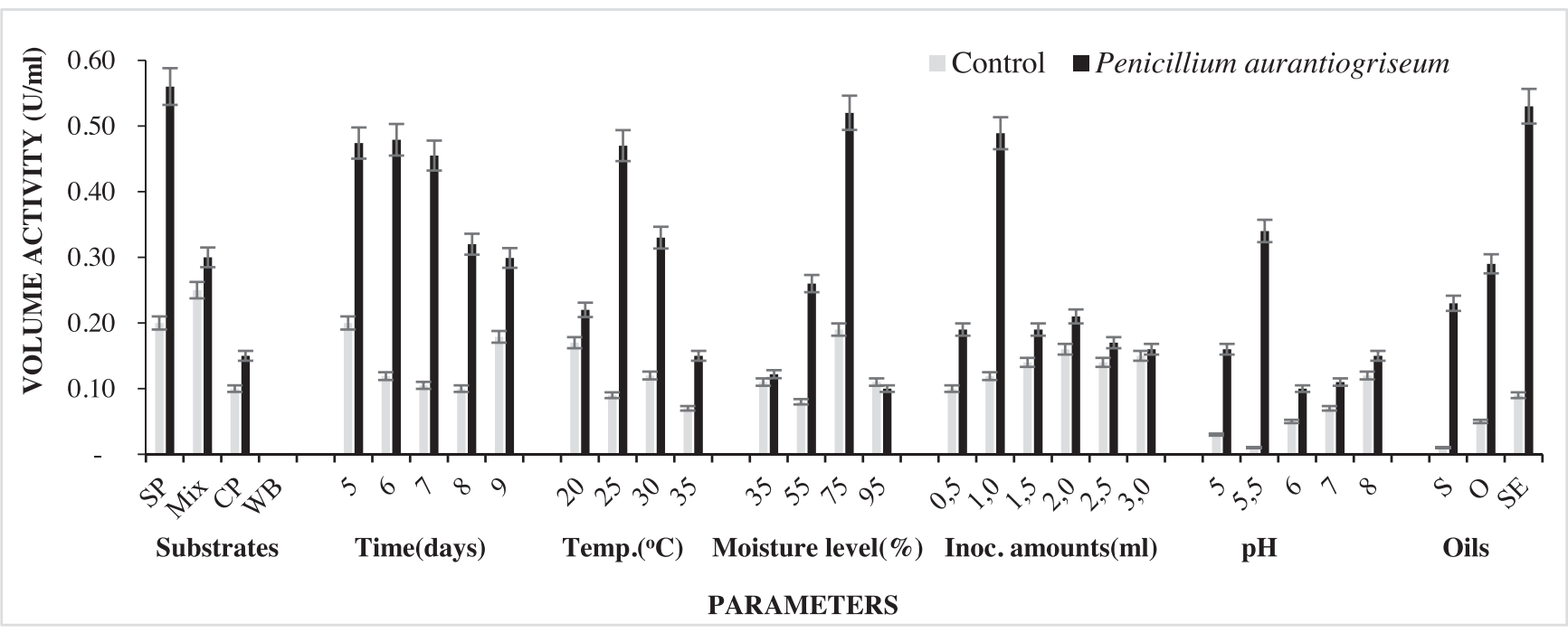

Fig. 1. Optimization of process parameters for lipase production by SSF from P. aurantiogriseum; substrates, incubation time, incubation temperature, moisture levels, initial inoculum amounts, moistening agents $\mathrm{pH}$, and vegetable oil supplement (control: SSF media not including microfungi; S: sunflower; O: olive; SE: sesame). 
3.9 Specific activity at determined optimum SSF culture media conditions

For fungal lipase produced in SSF medium, where optimum conditions were created, the volume activity was calculated as $0.4 \mathrm{U} / \mathrm{ml}$ and the specific activity as $1.13 \mathrm{U} / \mathrm{mg}$. The effect of optimization parameters on lipase activity was found to be statistically significant $(\mathrm{p}<0.05)$.

\section{Discussions}

Extracellular enzyme production investigations in SSF culture medium were carried out using Penicillium aurantiogriseum strain, because it showed the highest activity.

P. aurantiogriseum showed the highest extracellular lipase activity in SSF culture media containing SP as substrate. The lipase activity could not be determined in the SSF medium containing WB. Due to the high oil content and good water-holding capacity, enzyme production may have increased in the SSF medium containing SP. Sargin \& Göksungur (2007) stated that, in SSF environments, where WB and CP are used, these substrates with high starch content may cause the particles to swell because of the aggregation behavior of starch granules. With this swelling, breathing of the microorganisms and microbial growth may be negatively affected. These problems may have caused a low lipolytic activity in starch-containing substrates in our study.

It is known that enzymes, the primary metabolites, are produced in the log phase of microbial reproduction. Factors such as depletion of nutrients and stopping growth, synthesis of secondary metabolites, and interaction with other compounds in the medium may decrease enzyme synthesis. Several studies have been conducted on the optimum incubation time for maximum enzyme production. Rajan \& Nair (2011) reported that the optimum incubation time was the 7th day in lipase production from Aspergillus fumigatus, and Cihangir \& Sarıkaya (2004) stated that it was the 4th day in lipase production from Aspergillus sp.

In a study that produced lipase from Penicillium verrucosum by SSF method, it was reported that low temperatures reduce fungal metabolism, high temperatures can neutralize lipase, and excess temperature and moisture ratio reduce lipase production (Kempka et al., 2008). Other studies have shown that different microorganisms (even different strains of the same microorganism) have different optimum growth temperatures and that enzyme production is affected by different temperatures because of the growth kinetics of the microorganism. In a present study, although $P$. aurantiogriseum was a well-growing species at $30^{\circ} \mathrm{C}$, the enzyme production was not observed at this temperature. In other studies, optimum incubation temperatures are recorded as $20^{\circ} \mathrm{C}$ in lipase production from Penicillium candidum (Alhelli et al., 2018) and $29^{\circ} \mathrm{C}$ in lipase production from $P$. aurantiogriseum (Lima et al., 2003).

In our study, enzyme activities in different SSF media humidity levels $(35,55,75$, and $95 \%)$ were found as 0.01 , $0.18,0.37$, and 0 , respectively. The moisture retention capacity of substrates is an important factor for SSF method. Pandey (2003) reported that high moisturecontaining fermentation media may prevent the penetration of oxygen by decreasing substrate porosity and that low moisture level may lead to the reduction of nutrient availability, and thus poor microbial growth. Kempka et al. (2008) emphasized that low initial moisture of the substrate may result in the loss of functional properties of enzymes required for cell metabolism by preventing mass transfer. Optimum moisture levels varied between 50 and $80 \%$ in lipase production studies conducted by various researchers (Alhelli et al., 2018; Rehman et al., 2011; Gutarra et al., 2005). In our study, it was thought that the reason why $\% 75$ moisture was the best enzyme production level can be due to the high moisture capacity of SP.

Low levels of enzyme production can occur as a result of reaching of SSF media moisture to different levels via high inoculum amounts (high moisture can cause a decrease in substrate porosity, which prevents oxygen penetration). According to Riaz et al. (2003), an increase in the growth of microorganism due to the high amount of inoculum can significantly cause inadequacy of nutrients in the media. For this reason, metabolic activity of the organism and enzyme production may decline due to competition. It was reported that low inoculum level prolongs the time it takes for microorganisms to grow and use the substrate. Thus, optimizing the initial amount of inoculum in SSF environments is extremely important. In different enzyme studies, optimally, the optimum inoculation of $1 \mathrm{ml}$ was determined (Abdullah et al., 2014).

In the studies to determine the optimum $\mathrm{pH}$ for the production of lipase, moistening liquids at different pHs were prepared using buffers, and they were added 
to SSF media. In addition, distilled water with a $\mathrm{pH}$ of 5.5 was used as a natural agent. Optimum $\mathrm{pH}$ differed in lipase studies with different fungi by various researchers. Optimum $\mathrm{pH}$ was recorded as 7.0 in producing lipase from Candida sp. by Tan et al. (2003), while it was determined to be 5.5 for P. notatum by Rehman et al. (2011), and it was determined to be 5.5 for Aspergillus sp. by Cihangir \& Sarikaya (2004).

Vegetable oils are inexpensive carbon sources (Younas et al., 2015). Many researchers have added different sugars and oils to media as a carbon source in order to observe their effect on enzyme production (Lima et al., 2003; Kaya et al., 2013). Keklikçioğlu Çakmak \& Açıkel (2015) added vegetable oils such as soy, corn, olive, sunflower, and canola to SSF medium to increase lipase enzyme activity and observed the best activity in $1.25 \%$ soybean oil. Cihangir \& Sarikaya (2004) reported that a better lipase activity with the addition of olive oil to the medium was obtained. Sztajer \& Maliszewska (1989) used rapeseed oil as an inducer in their studies. Petrovic et al. (1990), in their study with Penicillium roqueforti, obtained the best lipase activity using $2 \%$ olive oil. Amin and Bhatti (2014) also used 2\% olive oil as inducer. According to Takaç \& Erdem (2009), also fatty acid ratios have an effect on the enzyme production. Researchers reported that if the oleic acid content of vegetable oils used was $30 \%$, and linoleic acid content was below $50 \%$, enzyme production decreased.

Maximum enzyme activities in lipase enzyme production studies with different Penicillium species were reported as $14.7 \mathrm{U} / \mathrm{g}$ (P. candidum) by Alhelli et al . (2018); $521 \mathrm{U} / \mathrm{g}$ (P. fellutanum) by Amin \& Bhatti (2014). The specific activity value $(1130 \mathrm{U} / \mathrm{g})$ found in our study is promising when compared to similar studies.

\section{Conclusion}

Extracellular lipases are among the most promising enzymes with biotechnological and environmental potential due to their specific catalytic properties. It is important to create new microbial sources where production is easier, cheaper, and faster for lipase production. Also, in this production, the usability of wastes as substrates is important. In this study, optimum fermentation conditions were obtained by SSF method using $P$. aurantiogriseum among the screened microfungi for lipase production. These conditions were determined as incubation time of 6 days, incubation temperature of $25 \mathrm{oC}$, distilled water as a moisture agent, initial moisture level $75 \%$, initial inoculum amount $1 \mathrm{ml}\left(1 \times 10^{6}\right.$ spores/ $\mathrm{ml}$ ), and $1 \%$ sesame oil as carbon source. As a result of the optimum conditions provided, the volume activity was calculated as $0.4 \mathrm{U} / \mathrm{ml}$, and the specific activity was $1.13 \mathrm{U} / \mathrm{mg}$. Compared with similar studies, the amount of lipase enzyme produced by Penicillium aurantiogriseum in SSF medium is promising in our study. However, this study showed that SP, an agricultural waste, can be used as a substrate in lipase production by the SSF method. In addition, this study may provide a basis for future lipase production research.

\section{ACKNOWLEDGEMENTS}

This study was supported by the Trakya University Scientific Research Project Unit, Edirne, Turkey (TUBAP 2017-89).

\section{References}

Abdullah, R., Shaheen, N. \& Iqtedar, M. (2014). Optimization of cultural conditions lterna production of alpha amylase by Aspergillus niger (Btm-26) in solid state fermentation. Pakistan Journal of Botany, 46(3): 1071-1078.

Alhelli, A.M., Abd Manap, M.Y., Mohammed, A.S., Mirhosseini, S.H., Sukor, R., et al. (2018). The extraction of crude enzyme of lipase from Penicillium candidum PCA 1/ TT031 by way of solid state fermentation. International Food Research Journal, 25:1-11.

Amin, M. \& Bhatti, H.N. (2014). Effect of physicochemical parameters on lipase production by Penicillium fellutanum using canola seed oil cake as substrate. International Journal of Agriculture and Biology, 16(1): 118-124.

Cardenas, F., Alvarez, E., Soledad, M., Alvarez, C., Maria, J., et al. (2001). Screening and catalytic activity in organic synthesis of novel fungal and yeast lipases. Journal of Molecular Catalysis B: Enzymatic, 14(4-6): 111-123.

Cihangir, N. \& Sarıkaya, E. (2004). Investigation of lipase production by a new isolate of Aspergillus sp. World Journal of Microbiology and Biotechnology, 20(2): 193-197.

de Almeida, A.F., Taulk-Tornisielo, S.M. \& Carmona, E.C. (2013). Influence of carbon and nitrogen sources on lipase production by a newly isolated Candida viswanathii strain. Annals of Microbiology, 63(4): 1225-1234. 
Ferreira, A.N., Ribeiro, D.D.S., Santana, R.A., Santos Felix, A.C., Alvarez, L.D.G., et al. (2017). Production of lipase from Penicillium sp. using waste oils and Nopalea cochenillifera. Chemical Engineering Communications, 204(10): 1167-1173.

Geoffry, K. \& Achur, R.N. (2018). Screening and production of lipase from fungal organisms. Biocatalysis and Agricultural Biotechnology, 14: 241-253.

Gutarra, M.L.E., Cavalcanti, E.C., Castilho, L.R., Freire, D.M.G. \& Júnior, G.L.S. (2005). Lipase production by solid-state fermentation cultivation conditions and operation of tray and packed-bed bioreactors. Applied Biochemistry and Biotechnology, 121(1-3): 105-116.

Hung, T.C., Giridhar, R., Chiou, S.H. \& Wu, W.T. (2003). Binary immobilization of Candida rugosa lipase on chitosan. Journal of Molecular Catalysis B: Enzymatic, 26(1-2): 69-78.

Iftikhar, T., Niaz, M., Anwer, M., Abbas, S.Q., Saleem, M., et al. (2011). Ecological screening of lipolytic cultures and process optimization for extracellular lipase production from fungal hyperproducer. Pakistan Journal of Botany, 43(2): 1343-1349.

Iftikhar, T., Niaz, M. \& Zia, M.A. (2010). Production of extracellular lipases by Rhizopus oligosporus in a stirred fermentor. Brazilian Journal of Microbiology, 41(1): 1124-1132.

Jain, R. \& Naik, S.N. (2018). Adding value to the oil cake as a waste from oil processing industry: Production of lipase in solid state fermentation. Biocatalysis and Agricultural Biotechnology, 15(1): 181-184.

Kaya, S., Önen, Y., Uyar, F. \& Akcan, N. (2013). Katı faz fermentasyonu (KFF) tekniği ile Bacillus subtilis ATCC 6051 'den $\alpha$-amilaz üretimi. Mus Alparslan University Journal of Science, 1(2): 119-126.

Keklikçioğlu Çakmak, N. \& Açıkel, Ü. (2015). Candida utilis mayasıla lipaz enzimi aktivitesinin farklı ortam koşullarında incelenmesi. Gazi Üniversitesi Mühendislik Mimarlık Fakültesi Dergisi, 30(3): 475-485.

Kempka, A.P., Lipke, N.L., da Luz Fontoura Pinheiro, T, Menoncin S, Treichel H, et al. (2008). Response surface method to optimize the production and characterization of lipase from Penicillium verrucosum in solid-state fermentation. Bioprocess and Biosystems Engineering, 31(2): 119-125.
Lima, V.M.G., Kieger, N., Mitchell, D.A. \& Fontana, J.D. (2004). Activity and stability of a crude lipase from Penicillium aurantiogriseum in aqueous media and organic solvents. Biochemical Engineering Journal, 18(1): 65-71.

Lima, V.M.G., Krieger, N., Sarquis, M.I., Mitchell, D.A., Ramos, L.P., et al. (2003). Effect of nitrogen and carbon sources on lipase production by Penicillium aurantiogriseum. Food Technology and Biotechnology, 41(2): 105-110.

Lowry, H.O., Rosebrough, N., Farr, A.L. \& Randall, R.J. (1951). Protein measurement with the folin phenol reagent. Journal of Biological Chemistry, 193(1): 265275 .

Malilas, W., Kang, S.W., Kim, S.B., Yoo, H.Y., Chulalaksananukul, W., et al. (2013). Lipase from Penicillium camembertii KCCM 11268: Optimization of solid state fermentation and application to biodiesel production. Korean Journal of Chemical Engineering, 30(5): 405-412.

Manoorkar, V.B. \& Gachande, B.D. (2015). Influence of physical factors on extracellular lipase production in storage seed borne fungi of some oil seeds. International Journal of Recent Scientific Research, 6(2): 2813-2816.

Martínez-Ruiz, A., Tovar-Castro, L., García, H.S., Saucedo-Castañeda, G. \& Favela-Torres, E. (2018). Continuous ethyl oleate synthesis by lipases produced by solid-state fermentation by Rhizopus microsporus. Bioresource Technology, 265: 52-58.

Pandey, A., Benjamin, S., Soccol, C.R., Nigam, P., Krieger, N., et al. (1999). The realm of microbial lipases in biotechnology. Biotechnology and Applied Biochemistry, 29(2): 119-131.

Pandey, A. (2003). Solid-state fermentation. Biochemical Engineering Journal, 13(2-3): 81-84.

Petroviç, S.E., Krinjar, M., Bedarevid, A., Vujicic, I.F. \& Banka, L. (1990). Effect of various carbon sources on microbial lipases biosynthesis. Biotechnology Letters, 12(4): 299-304.

Rajan, A. \& Nair, A.J. (2011). A comparative study on alkaline lipase production by a newly isolated Aspergillus fumigatus MTCC 9657 in submerged and solid-state fermentation using economically and industrially feasible substrate. Turkish Journal of Biology, 35(5): 569-574.

Rehman, S., Bhatti, H.N., Bhatti, I.A. \& Asgher, M. 
(2011). Optimization of process parameters for enhanced roduction of lipase by Penicillium notatum using agricultural waste, African Journal of Biotechnology, 10(84): 19580-19589.

Riaz, N., Haq, I.U. \& Qadder, M.A. (2003). Characterization of $\alpha$-amylase by Bacillus subtilis. Journal of Agriculture and Biology, 3: 249-252.

Rodrigues, C., Cassini, S.T.A., Antunes, P.W.P., Pinotti, L.M., Keller, R.P., et al. (2016). Lipase-producing fungi for potential wastewater treatment and bioenergy production. African Journal of Biotechnology, 15(18): 759-767.

Sadh, P.K., Chawla, P., Bhandari, L. \& Duhan, J.S. (2018). Bio-enrichment of functional properties of peanut oil cakes by solid state fermentation using Aspergillus oryzae. Journal of Food Measurement and Characterization, 12(1): 622-633.

Sargın, S. \& Göksungur, Y. (2007). Çeşitli tarımsal atık ve yan ürünlerin katı kültür fermantasyonu ile laktik asit üretiminde kullanılabilirliklerinin incelenmesi. Ege Üniversitesi Ziraat Fakültesi Dergisi, 44(3): 89-99.

Sarmah, N., Revathi, D., Sheelu, G., Yamuna Rani, K., Sridhar, S., et al. (2018). Recent advances on sources and industrial applications of lipases. Biotechnology Progress, 34(1): 5-28.

Shabbir, A. \& Mukhtar, H. (2018). Optimization process for enhanced extracellular lipases production from a new isolate of Aspergillus terreusah-F2. Pakistan Journal of Botany, 50(4): 1571-1578.

Singh, A.K. \& Mukhopadhyay, M. (2012). Overview of fungal lipase: A review. Applied Biochemistry and Biotechnology, 166(2): 486-520.

Sztajer, H. \& Maliszewska, I. (1989). The effect of culture conditions on lipolytic productivity of Penicillium citrinum. Biotechnology Letters, 2(12): 895-898.

Takac, S. \& Erdem, B. (2009). Media formulation using complex organic nutrients for improved activity, productivity, and yield of Candida rugosa lipase and esterase enzymes. Preparative Biochemistry and Biotechnology, 39(3): 323-341.

Takaç, S. \& Şengel, B.Ş. (2009). Extracellular lipolytic enzyme activity of a newly isolated Debaryomyces hansenii. Preparative Biochemistry \& Biotechnology, 40(1): 28-37.

Tan, T., Zhang, M., Wang, B., Ying, C. \& Deng, L.
(2003). Screening of high lipase producing Candida $s p$. and production of lipase by fermentation. Process Biochemistry, 39(4): 459-465.

Topal, Ş., Pembeci, C., Borcaklı, M., Batum, M. \& Çeltik, Ö. (2000). Türkiye'nin tarımsal mikoflorasının endüstriyel öneme sahip bazı enzimatik aktivitelerinin incelenmesi-I: amilaz, proteaz, lipaz. Turkish Journal of Biology, 24: 79-93.

Younas, T., Ali, I., \& Jamil, N. (2015). Polyhydroxyalkanotes (PHAs) production by using canola oil as carbon source from bacteria isolated near paper pulp industry. Kuwait Journal of Science, 42(2): 236-249.

Submitted : 19/05/2020

Revised : 04/08/2020

Accepted : 12/08/2020

DOI $\quad: 10.48129 /$ kjs.v48i1.9766 